\title{
The Resistance Mechanisms of Checkpoint Inhibitors in Solid Tumors
}

\author{
Evangelos Koustas ${ }^{1, \dagger}{ }^{+}$Panagiotis Sarantis ${ }^{1,+}$, Athanasios G. Papavassiliou ${ }^{1}(D)$ and \\ Michalis V. Karamouzis $1,2, *$ (iD \\ 1 Molecular Oncology Unit, Department of Biological Chemistry, Medical School, National and Kapodistrian \\ University of Athens, 11527 Athens, Greece; vang.koustas@gmail.com (E.K.); \\ panayotissarantis@gmail.com (P.S.); papavas@med.uoa.gr (A.G.P.) \\ 2 First Department of Internal Medicine, 'Laiko' General Hospital, Medical School, National and Kapodistrian \\ University of Athens, 11527 Athens, Greece \\ * Correspondence: mkaramouz@med.uoa.gr; Tel.: +30-210-746-2508 (ext. 9) \\ + These authors contributed equally to this work.
}

Received: 29 March 2020; Accepted: 23 April 2020; Published: 25 April 2020

\begin{abstract}
The emergence of cancer immunotherapy has already shown some remarkable results, having changed the treatment strategy in clinical practice for solid tumors. Despite these promising long-term responses, patients seem to lack the ability to respond to immune checkpoint inhibitors, thus demonstrating a primary resistance to immunotherapy. Moreover, a significant number of patients who initially respond to treatment eventually acquire resistance to immunotherapy. Both resistance mechanisms are a result of a complex interaction among different molecules, pathways, and cellular processes. Several resistance mechanisms, such as tumor microenvironment modification, autophagy, genetic and epigenetic alterations, tumor mutational burden, neo-antigens, and modulation of gut microbiota have already been identified, while more continue to be uncovered. In this review, we discuss the latest milestones in the field of immunotherapy, resistance mechanisms against this type of therapy as well as putative therapeutic strategies to overcome resistance in solid tumors.
\end{abstract}

Keywords: solid tumors; cancer; immunotherapy; resistance mechanism

\section{Introduction}

The concept of immune therapy to fight against cancer was first described in 1890 by W. Colley, who observed cancer remissions after inoculating sarcoma patients with erysipelas cultures [1] Significant progress has been made since then and has provided an in-depth understanding of tumor biology and interactions within the immune system. Further knowledge of the relationship between the immune system and cancer can be derived under the scope of a process named immune-editing, which comprises three distinct phases: elimination, equilibrium, and escape [2]. An intact immune system is capable of recognizing cancer cell's antigens as "non-self", and thus unleashing sufficient immune responses in order to induce elimination. Cancer cells surviving the elimination phase may rest in a dormant situation, unable to progress under the opposing forces of immune cells. In the escape phase, cancer cells are capable of altering their main characteristics with a loss of immunogenicity and/or antigenicity. Additionally, malignant cells can gain additional immunosuppressive properties, such as expression of programmed death-ligand 1 (PD-L1) or secretion of suppressive cytokines, which result in an additional reduction of their immunogenicity $[3,4]$.

The principal mode of action of the immune system is the recognition by cells of the innate immune system, the release of various cytokines, and complement activation and concomitant phagocytosis. Tumor development is associated with cytotoxic innate and adaptive immune cells, but as the tumor 
evolves from neoplastic tissue to detectable tumors, tumor cells use different mechanisms in order to create an immunosuppressive recapitulate peripheral immune tolerance [5].

This immune activation is under strict control by inhibitory checkpoints that prevent overstimulation, resulting in autoimmunity and extensive damage to healthy cells [6]. Unfortunately, tumor cells develop resistance mechanisms in order to avoid the presence of an efficient immune system. Tumor cells escape from immune response through two main mechanisms: avoiding the immune-cancer cell recognition and triggering an immunosuppressive tumor microenvironment (TME). Firstly, cancer cells rapidly decrease the expression of tumor antigens on the cell surface, thus avoiding being recognized by cytotoxic $\mathrm{T}$ cells. Moreover, tumor cell-derived factors initiate an immune-tolerant TME through (i) secretion of inhibitory checkpoint molecules (ii) induction of the recruitment of myeloid-derived suppressor cells (MDSCs), tumor-associated macrophages (TAMs) and regulatory T cells (Tregs) and (iii) expression of small suppressive molecules [4,7]. In order to evade immune destruction, tumor cells express inhibitory checkpoints that induce immune suppression, a mechanism that has been thoroughly investigated, which leads to the development of several molecules able to restrain cancer-induced immuno-suppression (i.e., anti-CTLA4, anti-PD1, and anti-PDL1). These immune checkpoint inhibitors now form a new landscape in cancer therapeutics, having shown remarkable response and survival rates in a variety of tumors. However, many cancer patients do not derive benefit from immune checkpoint inhibitors, an observation that has led to the assumption that resistance to immunotherapy may be present $[8,9]$.

Resistance to immunotherapy can be categorized as primary and acquired, depending on the presence or absence of initial response and subsequent relapse after the response that has been achieved. The mechanisms involved in the development of resistance include tumor-cell intrinsic and extrinsic factors that can either interfere with the antigen processing and presentation or enable tumors to recruit immune-suppressing cells that antagonize the activity of effectors cells [6]. With the advent of the immune checkpoint blockade, cancer therapeutics shifted from a tumor-cell focused approach to a broader concept of factors contributing to tumor formation. This has led to the recognition of the tumor microenvironment not only as a significant player supporting tumor growth and metastasis but also as a contributing one to the development of therapeutic resistance. In the context of immunotherapy, TME is regarded as a critical mediator of tumor-induced immuno-suppression through a variety of mechanisms, resulting in the down-regulation of both the effector T-cell activity and the recruitment of immunosuppressive cells [10].

\section{Immunotherapy in Solid Tumors}

The significant advance of the checkpoint inhibitors (anti-CTLA-4, anti-PD-1/PD-L1) has indicated as a hopeful therapeutic option in several solid tumors. CTLA-4 antibodies, like ipilimumab and tremelimumab, interrupt CTLA-4 from interacting with B7 and boost T-cell activation. The expression of CTLA-4 on tumors has been linked with poor survival in nasopharyngeal carcinoma [11] and increased survival in non-small cell lung cancer (NSCLC) [12]. The expression of PDL1 on tumor cells is high. On ligand binding by PD-L1, the PD-1 receptor inhibits the activation and proliferation of T-cells through a phosphatase, SHP-2, which de-phosphorylates the antigen receptor expressed by these cells. High PD-1/PD-L1 levels may associate with poor prognosis in some cancers (melanoma, esophageal, renal cell carcinoma, ovarian cancer) and with better prognosis in others (e.g., angiosarcoma and gastric cancer) [13]. PD-1 antibodies (such as nivolumab and pembrolizumab) and PD-L1 (such as atezolizumab) break off the interaction of PD-1 with PD-L1. In the last decade, numerous checkpoint inhibitors (e.g., ipilimumab, nivolumab, pembrolizumab, atezolizumab) got approval in various solid tumors such as melanoma, lung, renal, and bladder [14].

More specifically, in 2011, ipilimumab was the first approved checkpoint inhibitor, in patients with metastatic melanoma (shows better overall survival-OS). Pembrolizumab and nivolumab were also among the approved PD-1 inhibitors for advanced melanoma. Synergistic therapy with ipilimumab 
plus nivolumab led to better PFS compared to each drug being used separately (11.5 vs. 2.9 months only with ipilimumab and 6.9 months only with nivolumab) [15].

The first immunotherapy permitted (2015) was nivolumab for the treatment of patients with metastatic NSCLC. Between patients with advanced non-squamous NSCLC that had progressed during or after platinum-based chemotherapy, OS was better by $41 \%$ (nivolumab vs. docetaxel) [16]. Moreover, first-line treatment with nivolumab along with ipilimumab resulted in a better OS than only chemotherapy, in patients with NSCLC, independent of the PD-L1 expression [17].

Furthermore, the combination of nivolumab plus ipilimumab versus sunitinib shows significantly better OS rates among intermediate and poor-risk patients with previously untreated advanced renal-cell carcinoma [18].

Pembrolizumab was also used for second-line treatment of patients with NSCLC that express PD-L1. Additionally, it is authorized for the handling of patients with advanced NSCLC, high PDL1 expression, and metastatic melanoma patients and patients with recurrent/metastatic of the head and neck squamous cell carcinoma [14].

Atezolizumab (PD-L1 inhibitor), is already used for the treatment of patients with locally advanced or metastatic urothelial carcinoma due to its favorable safety profile compared to chemotherapy [19]. Moreover, the administration of atezolizumab versus bevacizumab plus chemotherapy significantly improved PFS and OS between patients with metastatic non-squamous NSCLC, independently of PD-L1 expression and EGFR/ALK genetic background [20].

\section{Resistance Mechanism}

PD-1/PD-L1 blockade appears to be promising immunotherapy with significant clinical benefits and durable responses in multiple tumor types. A percentage of cancer patients never demonstrate a clinical response or stabilized disease after treatment with checkpoint inhibitors. The estimated percentage of US cancer patients who are eligible for ICI (such as anti-PD-1/PD-L1, anti-CTLA4) increased from $1.54 \%$ in 2011 to $43.63 \%$ in 2018. Furthermore, the percentage of cancer patients estimated to respond to ICI was $0.14 \%$ in 2011 and increased to $12.46 \%$ in 2018 [21]. Different data from clinical studies suggest that the presence of pre-existing CD8+ T cells within the TME and the expression of PD-L1 and PD-1 on the tumor and T cells, respectively, predicted the response of patients to anti-PD-1 [22]. Therefore, several studies have highlighted the resistance mechanism against immunotherapy as a phenomenon in which CD8+ T-cells are either unable to recognize and localize to the tumor or are rendered ineffective despite their seemingly adequate localization [23]. Resistance mechanism against immunotherapy involves various mechanisms by which tumors can escape from the immune response.

\subsection{The Immunosuppressive Mechanism in TME}

The tumor microenvironment is a complicated structure that includes M2 macrophages, fibroblast, Tregs, myeloid-derived suppressor cells (MDSC), and other stromal cells [24].

Tregs are essential lymphocytes maintaining self-tolerance. This kind of T-cells is characterized by high expression of the FoxP3 transcription factor [25] and they can suppress effector T cells or (Teff) through secretion of inhibitory cytokines such as TGF-beta and/or IL-10 [26]. It is common for several kinds of tumors that are infiltrated by Tregs to depict such a pattern, and the lack of TME can restore this anti-tumor immunity [27].

A subtype of B-cells, which is known as B regulatory cells or B-regs, has been associated with autoimmunity, inflammation, and tumorigenesis [28]. B-regs are known as negative regulators of the immune response through suppression of cytotoxic CD8+/CD4+ Teffs, the secretion of anti-inflammatory cytokines (such as interleukin (IL)-10) [29,30] and the release of co-inhibitory molecules such as programmed cell death-ligand 1 or PD-L1 [31].

MDSCs are characterized by the expression of several molecules, such as CD11b and Gr-1 markers [32]. Different studies highlight the effect of MDSCs as a critical regulator mechanism of 
immune responses in cancer. Moreover, MDSCs regulate and promote cancer cell invasion and metastasis [32]. In addition, the presence of MDSCs in TME is correlated with resistance against immunotherapy and lower survival in different types of tumors such as colorectal and breast cancer [24].

Another essential type of white cells in TME is tumor-associated macrophages (TAMs), including M1 and M2 macrophages [33,34]. Several studies correlate TAMs with responses to immune therapies through suppression of T cell responses with PD-L1 [35]. Type M1 macrophages are associated with anti-tumor immunity and M2 with pro-tumorigenic properties [36,37].

TME is characterized by tumor-associated mast cells or TAMCs. This kind of cells is being recruited by chemotactic molecules that are secreted by cancer, immune and stromal cells such as prostaglandin $\mathrm{E}_{2}$ (PGE2), vascular endothelial growth factor (VEGF), CXC chemokine ligand (CXCL)12, fibroblast growth factor (FGF)-2, and platelet-derived growth factor (PDGF) [38]. Activated TAMCs release IL-33 (an essential cytokine for the activation of mast cell) and the C-C motif chemokine ligand (CCL)-5 (chemotactic factor) to further support the activation of mast cells into TME [38]. Moreover, TAMCs can also release a vast array of proteolytic enzymes and growth factors in order to promote immunosuppression, angiogenesis, tumorigenesis, and cancer cell invasion and metastasis [38, 39].

\subsection{Autophagy as a Modulator Mechanism for Antigen Presentation}

\subsubsection{The Association of Autophagy and the Immune System}

Autophagy is a well-described catabolic mechanism where molecules and damaged cellular organelles are degraded [40]. The primary step of autophagy is the formation of the autophagosome, a spherical structure with double-layer membranes, which consists of cytoplasmic contents and fuses with lysosomes [41]. The role of autophagy in cancer remains controversial [42]. This mechanism is associated with anticancer therapy by shaping hypoxic, metabolic, inflammatory, and immunosuppressive tumor microenvironments (TME) [43,44]. The autophagosome endosomal trafficking is closely connected with angiogenesis, immunosuppression and chronic inflammation, stromal formation, metastatic and the metabolic potential of cancer cells of TME $[43,45,46]$.

Several studies support the hypothesis that autophagy can alter the pool of antigenic peptides that are presented in the major histocompatibility complexes (MHC) I and II [47].

The fusion of New York esophageal squamous cell carcinoma-1 (NY-ESO-1), a specific antigen frequently over-expressed from melanoma to LC3, leads to the targeted autophagosome increasing response of NY-ESO-1-specific anti-melanoma helper T-cell [48]. Moreover, in autophagy based vaccination, autophagosomes from cancer cells are treated with proteasome inhibitors. These autophagosomes comprise tumor-associated antigens and, on the surface, express C-type lectin domain family 9 member A (CLEC9A) ligands that facilitate endocytosis by antigen-presenting cells (APCs) [49].

Dendritic cells (DCs) pulsed with such autophagosomes were more efficient in the response of OVA-specific T-cell compared to soluble protein [50]. It appears that this kind of autophagosome vaccination decreases the B16F10 melanoma cell viability, eliminated 3LL Lewis lung tumors, and preserved mice models from sarcoma [51]. Additionally, cancer cells may release autophagosomes, modulate autophagy machinery and positively alter the anticancer efficacy of T-cell in immune responses [52,53]. In a recent research article, the authors support the hypothesis that checkpoint inhibitors such as nivolumab, pembrolizumab, and ipilimumab activate the cytoprotective mechanism of autophagy in colorectal cancer cell lines [54].

\subsubsection{The Correlation of Autophagy and Antigen Presenting Cells}

It is well known that anti-tumor T-cells are activated via the identification of tumor peptides with immunogenic activity. These peptides are presented on the surface of antigen-presenting cells, such as DCs. Several studies highlight the essential role of the autophagy machinery in the regulation 
of the major histocompatibility complex (MHC) I and the antigen presentation on the surface of APCs such as macrophages and dendritic cells. In embryo mice, the expression of MHC class I on the cell surface of APCs was increased after treatment with autophagy inhibitors or knockdown of essential genes for autophagy regulation [55,56]. In a recent study, observed that slower trafficking of MHC-I consequently augmented CD8+ T cell activation [56]. Hence, due to a lack of autophagy initiation, observed higher expression and lower degeneration speed of MHC-I [51]. In vivo models, the absence of vacuolar protein sorting-associated protein 34 (VPS34) increased MHC-I and II expression on the DC surface [57]. In contrast, the expression of MHC-II on the cell surface of the macrophages was down-regulated after the inhibition of autophagy initiation with 3-methyladenine (3-MA) [51].

Several studies have highlighted the association of autophagy with the cross-presentation (the loading of MHC-I into APCs with immunogenic peptides) of antigens in DCs [43]. Increasing levels of autophagy were associated with the cross-presentation capability of bone marrow-derived DCs [56,58]. Moreover, the presentation of antigen in MHC-II was altered after autophagy inhibition with reduction of DC treatment intervened by an immune-dominant mycobacterial peptide with the reduced presentation of the vaccinia virus Ankara antigens and herpes simplex virus (HSV) antigens [59,60]. Thus, the initiation of T-cell response through antigen-specific peptides was decreased. So autophagy inhibition with specific agents altered the pool of immunogenic peptides, which is loaded in $\mathrm{MCH}$ and decreased the presentation of immune-dominant epitopes [61]. While autophagy inhibition increases the expression of MHC-I on the cell surface, it can alter the pool of peptides, which are loaded on MHC of DCs surface $[43,62,63]$.

\subsection{Genetic/Epigenetic Alteration in Cancer}

Several studies support the hypothesis that epigenetic alteration with DNA methyltransferase (or DNA MTase) and histone deacetylase (or HDAC) inhibitors as a putative target that increases the efficacy of ICI. These types of inhibitors increase the production of cytokines. They also increase antigen presentation by inhibiting Tregs [64]. In a recent study using a mouse model with ovarian cancer, inhibitors against DNA MTase augmented the production of immune-stimulatory chemokines such as CXCL9 or 10, and re-sensitized cancer cells to anti-PD-L1 MoAbs [65]. Moreover, in CRC and mammary carcinoma models, inhibition of histone deacetylase and DNA methyltransferase enhance response when combined with anti-CTLA- 4 and anti-PD-1 checkpoint inhibitors by downregulating MDSCs [66].

\subsection{Tumor Mutational Burden}

In a number of patients, the residual capacity of the immune system can be restored through exogenous tumor-infiltrating lymphocytes (TILs) or T-cells directed to cancer-specific immunogenic peptides. Although cancer cells are evolving in order to trigger antimmunosuppressive environment. This leads to genetic and/or epigenetic alterations that interrupt the formation of neo-antigen [67]. Consequently, this leads to antigens' inability to be recognized by cytotoxic lymphoid cells such as T-cells and decrease the sensitivity of tumor cells to immunotherapy, as it happened for cancer patients with large diffuse B-cell lymphoma; as a result CD19 loss of expression [68]. Furthermore, acquired resistance against immune checkpoint inhibitors (ICI) and Adoptive cell transfer (ACT) is developed through genetic alterations but also cancer cells and inhibition of antigen-immunogenic peptides complexes, as well as the activation of cytotoxic T-cell [69-71]. Several studies highlighted the positive correlation between the number of neo-antigens and high mutational burden with the response to ICIs [72-74]. The lack of cancer cell sensitivity to immunotherapy may also be the result of the abnormal growth of cancer cell clones within the tumor that do not produce neo-antigens [67]. Thus, the construction of genetically-modified T-cells with increased longevity remains the main target to avoid the resistance against immunotherapy. 


\subsection{Molecular Mechanisms as Immunosuppressive Mechanisms}

Several molecular mechanisms and oncogenes have been associated with resistance to immunotherapy in solid tumors.

The microphthalmia-associated transcription factor (MITF) is a well-known oncogene of melanoma, which is negatively associated with the invasion properties of cancer cells [75]. The MITD-depended resistance has already been described. Inhibition of eIF2B activates ATF4 and consequently AXL and suppresses MITF. This leads to resistance in adoptive T-cell and anti-PD-1 Monoclonal Antibodies (MoAbs) [76]. Furthermore, in melanoma, histone methyltransferase Ezh2 regulates the T-cell resistance against immunotherapy [77]. Ezh2-PRC2 protein complex regulates T-cell infiltration in melanoma. In a mice model, anti-CTLA4 MoAbs or IL-2 led in T-cells and TNF-a accumulation and Ezh2 expression, which caused immunogenicity loss of tumor, lower antigen expression and resistance to immunotherapy. Activation of Ezh2 in the same model re-established the immunogenicity of the tumor and inhibited melanoma growth [78]. Another crucial mechanism that affect ICI-based therapy are MicroRNA (miRNAs). miRNAs control tumorigenesis through the regulation of different genes and act as a resistance mechanism against immunotherapy [E30]. In melanoma, several miRNAs reveal acquired resistance to MAPK inhibitors as well as innate resistance to anti-PD-1 checkpoint inhibitors, which are both related to alterations of inflammatory and angiogenic pathways [78]. Other studies in melanoma and lung cancer support that miR-8 family target PD-L1 leads to an increase in the effectiveness of $\mathrm{CD}^{+} \mathrm{T}$-cell and tumor cell immunosurveillance. The increasing levels of the PD-L1/PD-1 molecules may be the result of the decreasing production of these miRNAs $[79,80]$.

The role of signal transduction pathways in cancer is well-described in many studies. In a melanoma animal model, the lack of phosphatase and tensin homolog (PTEN) activation decreased the infiltration of T-cells in tumors and increased the expression of immunosuppressive cytokines. Furthermore, VEGF was increased and led to immune suppression as it was highlighted through clinical samples and B16 murine tumors [81,82]. Moreover, loss of PTEN leads to autophagy inhibition through activation of the phosphoinositide 3-kinases (PI3K) signaling pathway, which had little effect on T-cells and immunotherapy $[83,84]$. In other human studies, the association between PTEN loss and resistance against PD-L1 MoAbs pembrolizumab was further confirmed [85,86].In addition, mutations in the JAK1/2 signaling pathway lead to resistance against anti-PD-1 MoAbs [87,88]. In colorectal cancer $(\mathrm{CRC})$ and melanoma patients with deficient mismatch repair (dMMR) system and resistance against anti-PD-1, several mutations in JAK1/2 were detected [87]. Another study also supports the hypothesis of the correlation between resistance to anti-PD-1 MoAbs and mutation on JAK1/2 [89]. Dysfunctional JAK1/2 leads to downregulation or lack of expression of PD-L1 through inactivation of the IFN- $\gamma$ receptor pathway and resistance against anti-PD-1/PD-L1 MoAbs [78]. The well-described Wnt signaling pathway is associated with several diseases, including cancer [90]. In a recent study, the authors highlighted the correlation between the $\mathrm{WNT} / \beta$-catenin axis and the loss of T-cell gene expression in metastatic melanoma samples [91]. Moreover, in metastatic melanoma, through immune exclusion, caused by deficient recruitment of dendritic cells (DC CD1031), the activation of the Wnt signaling pathway leads to the immunotherapy resistance of cancer cells against anti-PD-L1 and anti-CTLA-4 MoAbs [91,92].

Last, beta-2-microglobulin (B2M) is correlated with the heavy chain of MCH- I [93]. Mutations, deletion, or loss of heterozygosity harbored in this gene were detected in almost $30 \%$ of melanoma patients treated with ICI. Moreover, a mutation in B2M gene may alter the antigen presentation on MHC I and enrich three-fold in non-responders (30\%) compared to responders (10\%) along with more reduced OS in independent cohorts of patients with melanoma treated with anti-CTLA4 and anti-PD1 MoAbs respectively [94].

\subsection{The Relation between Gut Microbiota and Immune Response}

In the last decade, the association between gut microbiome and response to immune ICI is gaining interest. It is well-established that diet may alter the microbial composition. A study supported the 
hypothesis that fiber can trigger an immunostimulatory microbial landscape, which may lead to an increased response to ICI [95]. Moreover, probiotics may help to reshape the microbiome when they combine with ICI positively. In a melanoma mouse model, Bifidobacterium showed a synergistic effect with a PD-L1 checkpoint inhibitor [96].

Moreover, several studies highlighted the correlation between higher bacterial diversity (such as Faecalibacterium and Ruminococcaceae) enrichment of specific species and improved response to ICI [9,97]. The gut microbiome appears to modulate responses to anti-PD-1 checkpoint inhibitors in melanoma patients [98]. A recent study revealed that germ-free mice with fecal transplants from responders to ICI developed improved outcomes with anti-PD-L1 checkpoint inhibitors [99]. It is well known that antibiotics can alter the response to ICI through the modification of individual species [9,100-102]. The correlation between ICI response and microbiota is likely, via cross-reactivity between tumor neo-antigens and gut microbial, augmenting DC response, antigen presentation and the production of inflammatory cytokine [103,104]. In light of these results, several clinical trials have focused on investigating the influence of microbiome to immunotherapy response [105]. The predominant mechanisms are summarized in Figure 1.

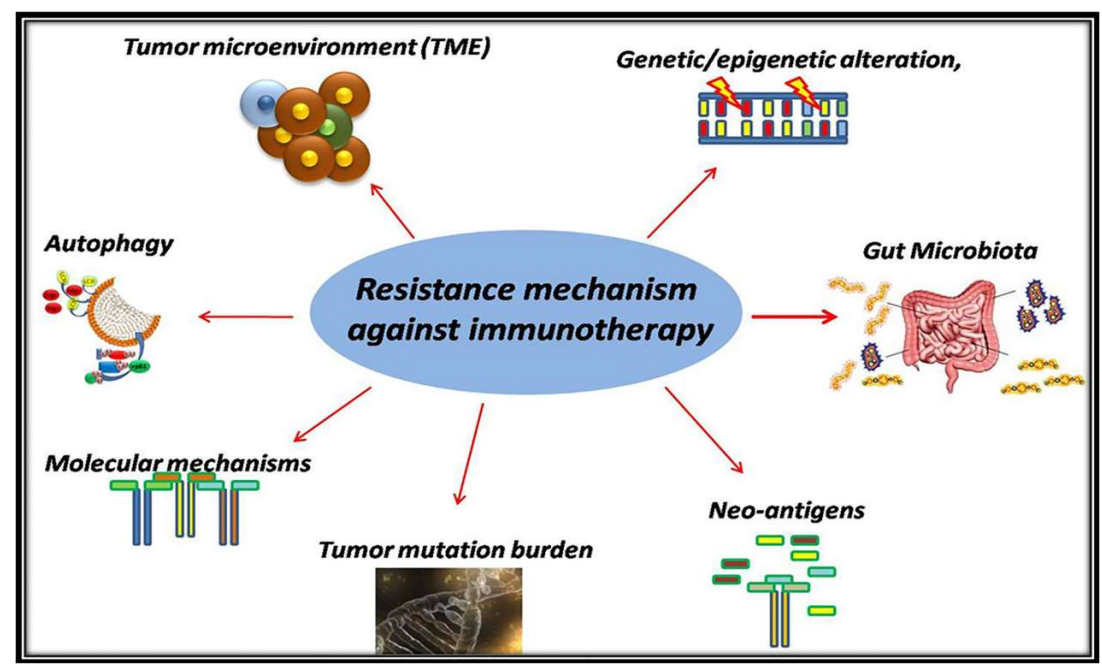

Figure 1. The predominant mechanisms of immunotherapy resistance in solid tumors. Several potential tumor-related mechanisms have already been identified as resistance mechanism against immunotherapy. Tumor microenvironment through the complexity of its structure, autophagy-depended antigen presentation on MHC I/II of antigen-presenting cells (APCs), tumor mutation burden and genetic/epigenetic alteration, molecular mechanism such as mutation several genes are the main mechanism of resistance in solid tumors.

\section{Ways to Overcome the Resistance Mechanism Against Checkpoint Inhibitors}

In recent years, the field of immune-oncology has established an increased understanding of molecular behavior of cancer, leading to the development of several therapeutics strategies, based on re-activation of immune system, against solid tumors. Despite the demonstrated successes of checkpoint inhibitors (ant-PD-1, anti-PD-L1, ant-CTLA4 etc.), most patients with solid tumors do not respond.

It is a common belief that PD-L1 expression in tumor cells immunohistochemistry (IHC) with the Tumor Proportional Score (TPS) is the only checkpoint inhibitor that is used as a predictive biomarker approved for NSCLC patients in first- and second-line treatment [106,107]. Unfortunately, checkpoint inhibitors against PD-1/PD-L1 have not been shown to play an essential role in predicting the immune response in other solid tumors or different settings. Moreover, the lack of PD-L1 expression in several cancers (as a biomarker), at a single time point may not fully represent the complexity of cancer cell communication network within TME [108,109]. 
The last years, research efforts revealed the complex and highly heterogeneous structure of TME. As it was mentioned before in the current review, TME is a main resistance mechanism against ICI. The following can be used to reduce the resistance of TME: (a) Upregulation of chemokines (CXCL) 9 and 10. Doxorubicin may induce the activity of CXCL10. The goal of a phase I/II study is to evaluate the effect of doxorubicin hydrochloride when given together with pembrolizumab in patients with sarcoma (NCT02888665); (b) activation of the endosomal toll-like receptors (TLRs) 3, 7, 8 and 9 [110]; (c) epigenetic silencing of Th1 cell-type chemokines; (d) blockade of the CXCL12/CXCR4 axis; (e) inhibition of MDSC using PI3K inhibitors;and (f) use of antiangiogenic drugs [111]. Several ongoing clinical trials try to investigate the role of antiangiogenic agents in order to enhance the effect of ICI. For example in a phase I/II study they combined lenvatinib (VEGFR inhibitor) with pembrolizumab in patients with advanced solid tumors (NCT02501096) (g) use of low molecular weight heparins (LMWHs) [112] (h) combined radiation therapy and PD-1/PD-L1 blockade, leading to an increased CD8+/Treg ratio and decreases immunosuppressive MDSCs. The investigators in a randomized Phase II clinical trial hypothesize that in a significant subset of patients with recurrent NSCLC immunotherapy (pembrolizumab) after stereotactic body radiation therapy (SBRT) (NCT02492568) will be superior to treatment with immunotherapy alone [113]. In a recent study, MHC I/II molecules appear to downregulated in resistance mutant Kras and p53-deficient lung cancer cells. However, local radiotherapy leads to increasing levels of IFN- $\beta$ and MHC I molecules on the cell surface of resistant cells. Thus, it is proved that adjuvant radiotherapy may help to overcome anti-PD-1 resistance, and then enhances the efficacy of anti-PD-1 checkpoint inhibitors [114]

An increasing amount of research data supports the hypothesis that targeting the structure of blood vessels can reduce the function of suppressive cells and promote the anti-tumor activity of immune effector cells within TME [115]. Currently, a plethora of clinical studies are underway in order to identify the impact of simultaneous inhibition of angiogenesis and checkpoint inhibitors. Moreover, many research teams are focusing on reprogramming TME in order to become more immune-stimulatory through a therapeutic scheme that combines anti-angiogenic agents and immune checkpoint inhibitors such as pembrolizumab and nivolomumab. In this contest, this combinatorial scheme appears to inhibit the negative immune signals and augment the ratio of anti-/pro-tumor immune cells. Furthermore, immunotherapy appears to restore immune-supportive TME and promote tumor-vascular normalization. These facts lead to an increase in the infiltration and activation of lymphocyte within the tumor [115].

In addition, several studies highlight the fact that anti-PD-L1 based immunotherapy appears to be more efficient when combined with chemotherapeutic agents [43]. On the other hand, different cancer types, such as breast or colorectal cancer, and melanoma, are identified through the higher expression of PD-L1 in both cancer and infiltrating immune cells [116]. Further, ongoing clinical studies are trying to evaluate the combinatorial scheme of anti-PD-1/-L1, MoAbs with other therapeutic agents such as copanlisib (PI3Kinase inhibitor) in elapsed/refractory solid tumors with expansions in mismatch-repair proficient (MSS) colorectal cancer patients (NCT03711058). In addition, other clinical trials combine platinum-based agents such as carboplatin with nivolumab in order to evaluate the pathological complete response defined as the absence of residual tumor in lung and lymph nodes comparing patients treated with chemo-immunotherapy versus chemotherapy alone. FOLFOX scheme also has been combined with ICI in several clinical trials (NCT03202758, NCT02375672, and NCT02997228). In a randomized phase 2 study will evaluate 2 novel immunotherapy combinations in which pembrolizumab is integrated with ramucirumab and paclitaxel in patients with advanced gastric and GEJ adenocarcinoma (NCT04069273) The main goal of this study is to examined the re-activation of the immune response against several types of cancer with therapeutic benefits for patients.

In addition, pembrolizumab as monotherapy could better suit a patient with a low tumor burden and a better performance status, than the combination of pembrolizumab and chemotherapy that would be more beneficial for a cancer patient with a higher tumor burden and a more inferior performance status, for whom a rapid and more probable response to treatment is crucial [117]. Furthermore, 
this very same problem could also arise with another anti-PD-1 drug, atezolizumab, apart from the positive results coming from the IMpower150 clinical trial. Moreover, atezolizumab also showed interesting results in a recent study from the IMpower110. In this study, 555 high PD-L1 expressing (TC3/IC3) naïve nonsquamous or squamous advanced NSCLC-affected patients without positive genetic biomarkers were respectively randomized (1:1) to receive atezolizumab monotherapy vs. cis/carboplatin + pemetrexed or atezolizumab monotherapy vs. cis/carboplatin + gemcitabine and results decisively favored atezolizumab over SoC chemotherapy: mOS: 20.2 vs. 13.1 months (HR for death: 0.595) [117].

The crucial role of autophagy as a regulator mechanism for energy and metabolic balance in tumor cells is well described previously. The last decade research efforts have led to the development of agents that modulate autophagy. Chloroquine (CQ) and its derivative, hydroxychloroquine (HCQ), is one of the most studied inhibitors that target the fusion of the autophagosome with a lysosome [43]. Several studies indicate that autophagy inhibition in cancer cells may be a putative an approach to improve the effect of ICI. High-dose IL-2 (HDIL-2) alone has been found to be beneficial for immunotherapy in an advanced murine metastatic liver tumor model especially after co-treatment with CQ. It is known that IL-2 reduces tumorgenesis through initiation of immune cell proliferation and infiltration in the liver and spleen [118]. In another study in renal cell carcinoma, autophagy inhibition by CQ also increased the effect of HDIL-2 on stimulation of T-cells, NK cells and DCs [119]. In addition, combination of 3-MA and IL-24 induced apoptosis in oral squamous cell carcinomas (OSCC) [120]. Furthermore, as it was mentioned before in the current review, ICI such as nivolumab, pembrolizumab or ipilimumab can trigger the cytoprotective autophagy in CRC cell lines. The combination of Hydroxychloroquine or HCQ (autophagy inhibitor) and checkpoint inhibitors trigger apoptotic cell death in MSHI-H CRC cell lines [54]. The clinical response of CQ and it derivative HCQ appears to vary widely. Both of them are not specific inhibitors of autophagy and affect also other cellular functions [43]. Thus, a plethora other agents that modulate autophagy (inhibitors or promoters) have already been developed [43]. The impact of autophagy on tumorgenesis and its active participation in antigen presentation from MHC-I and/or MHC-II make autophagy an attractive target for solid tumor ICI-depended therapy.

As it was mentioned, mutation in different genes and the signaling pathways that control have been targeted from many research teams in order to overcome the resistance against ICI. The phase I/II trial studies (NCT04317105) tries to investigate the side effects and best dose of copanlisib (dual inhibitor of PI3K $\alpha$ and $\delta$ isoforms) when given together with nivolumab and ipilimumab in treating patients with solid cancers that have spread to other places in the body (advanced) with mutation in PIK3CA and PTEN genes. A novel small inhibitor CGX1321 (inhibitor of WNT pathways) has already entered in human clinical trials as an anti-cancer agent. Keynote 596 uses single agent dose expansion phase in gastrointestinal (GI) tumors and roll-over cohort of CGX1321 and pembrolizumab in subjects who have progressed on single agent CGX1321 and Phase 1b consisting of CGX1321 in combination with pembrolizumab in colorectal tumors. Both phases of this study try to evaluate the safety, pharmacokinetics, and clinical activity of this combinatorial treatment (NCT02675946)

In addition, several inhibitor of the histone lysine methyltransferase EZH2 such as CPI-1205 are already developed. In a Phase I/II clinical study (NCT03525795), combine CPI-1205 with ipilimumab in patients with histologically or cytologically confirmed advanced solid tumors. To avoid this resistance caused by gut microbiota, antibiotics, prebiotics (dietary or chemical entities), and synbiotics can be used.

Moreover, the food industry have been applied recently bacteriophages, to eliminate unfavorable bacteria [121]. Furthermore, gut microbiota have begun to attract many research team as putative target for solid tumors. In clinical trial with clinicaltrials.gov: NCT03829111 the investigators try to combine checkpoint inhibitors such as nivolumab and Ipilimumab with probiotics. This phase I trial study tries to investigate the effect of CBM588 probiotic in patients with kidney cancer (stage IV) that are treated with nivolumab and ipilimumab. 
In Table 1 are presented several ongoing clinical trials that try to combined checkpoint inhibitors with other agents in order to overcome the resistance against ICI.

Table 1. Clinical studies with combination of immunotherapy with chemotherapy in solid tumors.

\begin{tabular}{|c|c|c|c|}
\hline Number of Study. & Type of Cancer & Phase & Agent/Compound \\
\hline NCT04069273 & $\begin{array}{l}\text { Adenocarcinomas of the } \\
\text { esophagogastric junction }\end{array}$ & II & $\begin{array}{c}\text { Ramucirumab + pembrolizumab } \\
\text { + paclitaxel }\end{array}$ \\
\hline NCT02501096 & Advanced solid tumors & $\mathrm{I} / \mathrm{II}$ & Lenvatinib + pembrolizumab \\
\hline NCT02646748 & Advanced solid tumors & I & Pembrolizumab+INCB combinations \\
\hline NCT04317105 & $\begin{array}{l}\text { Advanced malignant } \\
\text { solid neoplasm }\end{array}$ & $\mathrm{I} / \mathrm{II}$ & Copanlisib, ipilimumab, nivolumab \\
\hline NCT03525795 & Advanced solid tumors & $\mathrm{I} / \mathrm{II}$ & CPI-1205, ipilimumab \\
\hline NCT02617589 & Brain cancer & III & Nivolumab, temozolomide \\
\hline NCT02684006 & Clear cell & III & Avelumab + axitinib vs. sunitinib \\
\hline NCT02853331 & Clear cell & III & Pembrolizumab + axitinib vs. sunitinib \\
\hline NCT01472081 & Clear cell/non-clear cell & I & Nivolumab + sunitib/pazopanib \\
\hline NCT02420821 & Clear cell, sarcomatoid & III & Atezolizumab+bevacizumab vs. sunitib \\
\hline NCT03202758 & Colorectal cancer & $\mathrm{I} / \mathrm{II}$ & Durvalumab, tremelimumab and FOLFOX \\
\hline NCT02981524 & Colorectal cancer & II & $\begin{array}{l}\text { Cyclophosphamide followed by } \\
\text { Pembrolizumab }\end{array}$ \\
\hline NCT03657641 & Colorectal cancer & $\mathrm{I} / \mathrm{II}$ & Pembrolizumab + vicriviroc \\
\hline NCT02375672 & Colorectal cancer & II & Pembrolizumab + FOLFOX \\
\hline NCT03711058 & Colorectal cancer & $\mathrm{I} / \mathrm{II}$ & Nivolumab + copanlisi, nivolumab \\
\hline NCT02327078 & Colorectal cancer & VII & Nivolumab + epacadostat \\
\hline NCT03832621 & Colorectal cancer & II & Nivolumab, ipilimumab, temozolomide \\
\hline NCT02675946 & Gastrointestinal cancers & I & CGX1321+pembrolizumab \\
\hline NCT02496208 & Genitourinary tumors & I & Cabozantinib + nivolumab/ipilimumab \\
\hline NCT02997228 & $\mathrm{mCRC}$ & III & $\begin{array}{l}\text { Atezolizumab + bevacizumab }+ \\
\text { mFOLFOX6 }\end{array}$ \\
\hline NCT01950390 & Melanoma & II & Ipilimumab + bevacizumab \\
\hline NCT02802098 & Metastatic breast cancer & I & $\begin{array}{c}\text { Durvalumab }+ \text { bevacizumab, taxane+ } \\
\text { bevacizumab }\end{array}$ \\
\hline NCT00790010 & Metastatic melanoma & I & Ipilimumab, bevacizumab \\
\hline NCT02959554 & $\begin{array}{l}\text { Metastatic renal cell } \\
\text { carcinoma }\end{array}$ & II & Nivolumab after sunitinib/pazopanib \\
\hline NCT03149822 & $\begin{array}{l}\text { Metastatic renal cell } \\
\text { carcinoma }\end{array}$ & $\mathrm{I} / \mathrm{II}$ & Pembrolizumab + cabozantinib \\
\hline NCT02681549 & mNSCLC & II & Pembrolizumab + bevacizumab \\
\hline NCT03976375 & mNSCLC & III & Pembrolizumab, lenvatinib, docetaxel \\
\hline NCT03838159 & NSCLC & II & Paclitaxel, carboplatin, nivolumab \\
\hline NCT03425006 & NSCLC & II & Itacitinib, Pembrolizumab \\
\hline NCT02492568 & NSCLC & II & SBRT, pembrolizumab \\
\hline NCT02443324 & $\begin{array}{l}\text { NSCLC, Biliary tract } \\
\text { carcinoma, Urothelial } \\
\text { carcinoma }\end{array}$ & I & Ramucirumab + pembrolizumab \\
\hline NCT03153410 & Pancreatic cancer & I & $\begin{array}{c}\text { Pembrolizumab, GVAX, cyclophosphamide, } \\
\text { IMC-CS4 }\end{array}$ \\
\hline NCT02648282 & Pancreatic cancer & II & Pembrolizumab, GVAX, cyclophosphamide \\
\hline NCT03563248 & Pancreatic cancer & II & Nivolumab, losartan, FOLFIRINOX \\
\hline NCT03829111 & Renal Cell carcinoma & I & $\begin{array}{l}\text { Nivolumab, Ipilimumab, Clostridium } \\
\text { butyricum CBM } 588 \text { probiotic strain }\end{array}$ \\
\hline NCT02888665 & Sarcoma & $\mathrm{I} / \mathrm{II}$ & Doxorubicin + pembrolizumab \\
\hline NCT03898180 & Urothelial carcinoma & III & Lenvatinib + pembrolizumab \\
\hline
\end{tabular}

NCT: national clinical trial; mCRC: metatstatic colorectal cancer; mNSCLC: metastatic nonsquamous non-small cell lung cancer; FOLFOX: folinic acid, fluorouracil, and oxaliplatin; mFOLFOX6: leucovorin calcium (folinic acid), fluorouracil, and oxaliplatin; GVAX: cancer vaccine which includes granulocyte-macrophage colony-stimulating factor (GM-CSF); IMC-CS4: a monoclonal antibody targeted to the colony-stimulating factor receptor (CSF-1 receptor or CSF-1R); FOLFIRINOX: 5-fluorouracil, leucovorin, irinotecan, and oxaliplatin; SBRT: Stereotactic body radiation therapy. 


\section{Conclusions}

In recent years, the vigorous attempt in the field of oncology and immunology has produced an increased amount of knowledge in tumor biology, leading to the development of several therapeutic strategies linked to the immune system. Despite the established successes of immunotherapy in solid tumors, a remarkable amount of patients with different types of cancers do not respond. Several mechanisms such as tumor microenvironment, immune cell infiltration within the tumor, poor antigen presentation, autophagy, molecular mechanisms, and silence of the immune response through cytokine release have already been identified as immunosuppressive factors in solid tumors. However, additional mechanisms continue to be discovered and further reveal the complexity of interactions between the tumor and the immune system. Myriad of research studies and clinical trials try to overcome the resistance mechanism against immunotherapy through the combination of anti-PD-1/PD-L1 or other checkpoint inhibitors with anti-angiogenic factors with traditional chemotherapy. In the future, research efforts should focus on the understanding of tumor microenvironment structure in order to re-active and sensitize tumor cells on immunotherapy. Putative therapeutic strategies will be developed in order to overcome the anti-tumor immune resistance against immunotherapy for different types of cancer.

Author Contributions: E.K., P.S., A.G.P. and M.V.K. made substantial contributions in the conception, design and interpretation of the data; A.G.P. and M.V.K. made substantial contributions in drafting the manuscript and revising it critically for valuable intellectual content; E.K. and P.S. made substantial contributions to acquisition, analysis and interpretation of data. All authors contributed to data analysis, drafting and revising the article, gave final approval of the version to be published, and agree to be accountable for all aspects of the work. The manuscript has been read and approved by all named authors and that there are no other persons who satisfied the criteria for authorship but are not listed. The order of authors listed in the manuscript has been approved by all of us. All authors have no consideration of intellectual property associated with this work and there are no impediments to publication, including the timing of publication, with respect to intellectual property. All authors have followed the regulations of their institutions concerning intellectual property. All authors have read and agreed to the published version of the manuscript.

Funding: The authors declare that no funding was needed for the completion of this project.

Conflicts of Interest: The authors declare no potential conflicts of interest.

\section{References}

1. Decker, W.K.; Da Silva, R.F.; Sanabria, M.H.; Angelo, L.S.; Guimarães, F.; Burt, B.M.; Kheradmand, F.; Paust, S. Cancer Immunotherapy: Historical Perspective of a Clinical Revolution and Emerging Preclinical Animal Models. Front. Immunol. 2017, 8, 829. [CrossRef] [PubMed]

2. Beatty, G.L.; Gladney, W.L. Immune escape mechanisms as a guide for cancer immunotherapy. Clin. Cancer Res. 2014, 21, 687-692. [CrossRef] [PubMed]

3. Oiseth, S.J.; Aziz, M.S. Cancer immunotherapy: A brief review of the history, possibilities, and challenges ahead. J. Cancer Metastasis Treat. 2017, 3, 250. [CrossRef]

4. Gonzalez, H.; Hagerling, C.; Werb, Z. Roles of the immune system in cancer: From tumor initiation to metastatic progression. Genome Res. 2018, 32, 1267-1284. [CrossRef]

5. Pio, R.; Ajona, D.; Ortiz-Espinosa, S.; Mantovani, A.; Lambris, J.D. Complementing the Cancer-Immunity Cycle. Front. Immunol. 2019, 10, 774. [CrossRef]

6. Seliger, B.; Hu-Lieskovan, S.; Wargo, J.A.; Ribas, A. Primary, Adaptive, and Acquired Resistance to Cancer Immunotherapy. Cell 2017, 168, 707-723. [CrossRef]

7. Kitamura, T.; Qian, B.-Z.; Pollard, J.W. Immune cell promotion of metastasis. Nat. Rev. Immunol. 2015, 15, 73-86. [CrossRef]

8. Young, K.; Hughes, D.J.; Cunningham, D.; Starling, N. Immunotherapy and pancreatic cancer: Unique challenges and potential opportunities. Ther. Adv. Med. Oncol. 2018, 10, 1758835918816281. [CrossRef]

9. Fares, C.; Van Allen, E.M.; Drake, C.G.; Allison, J.P.; Hu-Lieskovan, S. Mechanisms of Resistance to Immune Checkpoint Blockade: Why Does Checkpoint Inhibitor Immunotherapy Not Work for All Patients? Am. Soc. Clin. Oncol. Educ. Book 2019, 39, 147-164. [CrossRef] 
10. Whiteside, T.L. The tumor microenvironment and its role in promoting tumor growth. Oncogene 2008, 27, 5904-5912. [CrossRef]

11. Huang, P.-Y.; Guo, S.-S.; Zhang, Y.; Lu, J.-B.; Chen, Q.-Y.; Tang, L.-Q.; Zhang, L.; Liu, L.-T.; Zhang, L.; Mai, H.-Q. Tumor CTLA-4 overexpression predicts poor survival in patients with nasopharyngeal carcinoma. Oncotarget 2016, 7, 13060-13068. [CrossRef] [PubMed]

12. Salvi, S.; Fontana, V.; Boccardo, S.; Merlo, D.F.; Margallo, E.; Laurent, S.; Morabito, A.; Rijavec, E.; Bello, M.G.D.; Mora, M.; et al. Evaluation of CTLA-4 expression and relevance as a novel prognostic factor in patients with non-small cell lung cancer. Cancer Immunol. Immunother. 2012, 61, 1463-1472. [CrossRef] [PubMed]

13. Seidel, J.; Otsuka, A.; Kabashima, K. Anti-PD-1 and Anti-CTLA-4 Therapies in Cancer: Mechanisms of Action, Efficacy, and Limitations. Front. Oncol. 2018, 8, 8. [CrossRef] [PubMed]

14. Soliman, H. nab-Paclitaxel as a potential partner with checkpoint inhibitors in solid tumors. OncoTargets Ther. 2016, 10, 101-112. [CrossRef]

15. Larkin, J.; Sileni, V.C.; Gonzalez, R.; Grob, J.-J.; Cowey, C.L.; Lao, C.D.; Schadendorf, D.; Dummer, R.; Smylie, M.; Rutkowski, P.; et al. Combined Nivolumab and Ipilimumab or Monotherapy in Untreated Melanoma. N. Engl. J. Med. 2015, 373, 23-34. [CrossRef]

16. Borghaei, H.; Paz-Ares, L.; Horn, L.; Spigel, D.R.; Steins, M.; Ready, N.E.; Chow, L.Q.; Vokes, E.; Felip, E.; Holgado, E.; et al. Nivolumab versus Docetaxel in Advanced Nonsquamous Non-Small-Cell Lung Cancer. N. Engl. J. Med. 2015, 373, 1627-1639. [CrossRef]

17. Hellmann, M.D.; Paz-Ares, L.; Caro, R.B.; Zurawski, B.; Kim, S.-W.; Costa, E.C.; Park, K.; Alexandru, A.; Lupinacci, L.; Jimenez, E.D.L.M.; et al. Nivolumab plus Ipilimumab in Advanced Non-Small-Cell Lung Cancer. N. Engl. J. Med. 2019, 381, 2020-2031. [CrossRef]

18. Motzer, R.J.; Rini, B.I.; McDermott, D.F.; Frontera, O.A.; Hammers, H.J.; Carducci, M.A.; Salman, P.; Escudier, B.; Beuselinck, B.; Amin, A.; et al. Nivolumab plus ipilimumab versus sunitinib in first-line treatment for advanced renal cell carcinoma: Extended follow-up of efficacy and safety results from a randomised, controlled, phase 3 trial. Lancet Oncol. 2019, 20, 1370-1385. [CrossRef]

19. Powles, T.; Durán, I.; Van Der Heijden, M.S.; Loriot, Y.; Vogelzang, N.J.; De Giorgi, U.; Oudard, S.; Retz, M.M.; Castellano, D.; Bamias, A.; et al. Atezolizumab versus chemotherapy in patients with platinum-treated locally advanced or metastatic urothelial carcinoma (IMvigor211): A multicentre, open-label, phase 3 randomised controlled trial. Lancet 2018, 391, 748-757. [CrossRef]

20. Socinski, M.A.; Jotte, R.M.; Cappuzzo, F.; Orlandi, F.; Stroyakovskiy, D.; Nogami, N.; Rodríguez-Abreu, D.; Moro-Sibilot, D.; Thomas, C.A.; Barlesi, F.; et al. Atezolizumab for First-Line Treatment of Metastatic Nonsquamous NSCLC. N. Engl. J. Med. 2018, 378, 2288-2301. [CrossRef]

21. Haslam, A.; Prasad, V. Estimation of the Percentage of US Patients With Cancer Who Are Eligible for and Respond to Checkpoint Inhibitor Immunotherapy Drugs. JAMA Netw. Open 2019, 2, e192535. [CrossRef] [PubMed]

22. Tumeh, P.C.; Harview, C.; Yearley, J.H.; Shintaku, I.P.; Taylor, E.J.M.; Robert, L.; Chmielowski, B.; Spasić, M.; Henry, G.; Ciobanu, V.; et al. PD-1 blockade induces responses by inhibiting adaptive immune resistance. Nature 2014, 515, 568-571. [CrossRef] [PubMed]

23. Nowicki, T.; Hu-Lieskovan, S.; Ribas, A. Mechanisms of Resistance to PD-1 and PD-L1 Blockade. Cancer J. 2018, 24, 47-53. [CrossRef] [PubMed]

24. Rodriguez-Pascual, J.; Ayuso-Sacido, A.; Belda-Iniesta, C. Drug resistance in cancer immunotherapy: New strategies to improve checkpoint inhibitor therapies. Cancer Drug Resist. 2019, 2, 980-993. [CrossRef]

25. Samstein, R.M.; Arvey, A.; Josefowicz, S.Z.; Peng, X.; Reynolds, A.; Sandstrom, R.; Neph, S.; Sabo, P.; Kim, J.M.; Liao, W.; et al. Foxp3 Exploits a Pre-Existent Enhancer Landscape for Regulatory T Cell Lineage Specification. Cell 2012, 151, 153-166. [CrossRef]

26. Kim, J.-H.; Kim, B.S.; Lee, S.-K. Regulatory T Cells in Tumor Microenvironment and Approach for Anticancer Immunotherapy. Immune Netw. 2020, 20, e4. [CrossRef]

27. Tanaka, A.; Sakaguchi, S. Regulatory T cells in cancer immunotherapy. Cell Res. 2017, 27, 109-118. [CrossRef]

28. Mauri, C.; Menon, M. Human regulatory B cells in health and disease: Therapeutic potential. J. Clin. Investig. 2017, 127, 772-779. [CrossRef]

29. Carter, N.A.; Rosser, E.C.; Mauri, C. Interleukin-10 produced by B cells is crucial for the suppression of Th17/Th1 responses, induction of $\mathrm{T}$ regulatory type 1 cells and reduction of collagen-induced arthritis. Arthritis Res. Ther. 2012, 14, R32. [CrossRef] 
30. DiLillo, D.J.; Matsushita, T.; Tedder, T.F. B10 cells and regulatory B cells balance immune responses during inflammation, autoimmunity, and cancer. Ann. N. Y. Acad. Sci. 2010, 1183, 38-57. [CrossRef]

31. Saleh, R.; Elkord, E. Acquired resistance to cancer immunotherapy: Role of tumor-mediated immunosuppression. Semin. Cancer Boil. 2019, 27, 30171-30173. [CrossRef] [PubMed]

32. Dysthe, M.; Parihar, R. Myeloid-Derived Suppressor Cells in the Tumor Microenvironment. Adv. Exp. Med. Biol. 2020, 1224, 117-140. [CrossRef]

33. Jayasingam, S.D.; Citartan, M.; Thang, T.H.; Zin, A.A.M.; Ang, K.C.; Ch'Ng, E.S. Evaluating the Polarization of Tumor-Associated Macrophages Into M1 and M2 Phenotypes in Human Cancer Tissue: Technicalities and Challenges in Routine Clinical Practice. Front. Oncol. 2020, 9, 1512. [CrossRef] [PubMed]

34. Sarantis, P.; Koustas, E.; Papadimitropoulou, A.; Papavassiliou, A.G.; Karamouzis, M.V. Pancreatic ductal adenocarcinoma: Treatment hurdles, tumor microenvironment and immunotherapy. World J. Gastrointest. Oncol. 2020, 12, 173-181. [CrossRef] [PubMed]

35. Kuang, D.-M.; Zhao, Q.; Peng, C.; Xu, J.; Zhang, J.-P.; Wu, C.; Zheng, L. Activated monocytes in peritumoral stroma of hepatocellular carcinoma foster immune privilege and disease progression through PD-L1. J. Exp. Med. 2009, 206, 1327-1337. [CrossRef]

36. Ostuni, R.; Kratochvill, F.; Murray, P.J.; Natoli, G. Macrophages and cancer: From mechanisms to therapeutic implications. Trends Immunol. 2015, 36, 229-239. [CrossRef]

37. Zhou, J.; Tang, Z.; Gao, S.; Li, C.; Feng, Y.; Zhou, X. Tumor-Associated Macrophages: Recent Insights and Therapies. Front. Oncol. 2020, 10, 188. [CrossRef]

38. Oldford, S.A.; Marshall, J.S. Mast cells as targets for immunotherapy of solid tumors. Mol. Immunol. 2015, 63, 113-124. [CrossRef]

39. Maciel, T.; Moura, I.C.; Hermine, O. The role of mast cells in cancers. F1000Prime Rep. 2015, 7, 09. [CrossRef]

40. Koustas, E.; Karamouzis, M.V.; Mihailidou, C.; Schizas, D.; Papavassiliou, A.G. Co-targeting of EGFR and autophagy signaling is an emerging treatment strategy in metastatic colorectal cancer. Cancer Lett. 2017, 396, 94-102. [CrossRef]

41. Aredia, F.; Guamán-Ortiz, L.M.; Giansanti, V.; Scovassi, A.I. Autophagy and Cancer. Cells 2012, 1, $520-534$. [CrossRef]

42. Yun, C.W.; Lee, S.H. The Roles of Autophagy in Cancer. Int. J. Mol. Sci. 2018, 19, 3466. [CrossRef] [PubMed]

43. Koustas, E.; Sarantis, P.; Kyriakopoulou, G.; Papavassiliou, A.G.; Karamouzis, M.V. The Interplay of Autophagy and Tumor Microenvironment in Colorectal Cancer-Ways of Enhancing Immunotherapy Action. Cancers 2019, 11, 533. [CrossRef] [PubMed]

44. Koustas, E.; Sarantis, P.; Papavassiliou, A.G.; Karamouzis, M. V Upgraded role of autophagy in colorectal carcinomas. World J. Gastrointest. Oncol. 2018, 10, 367-369. [CrossRef] [PubMed]

45. Kroemer, G.; Mariño, G.; Levine, B. Autophagy and the Integrated Stress Response. Mol. Cell 2010, 40, 280-293. [CrossRef]

46. Schaaf, M.B.; Houbaert, D.; Meçe, O.; Agostinis, P. Autophagy in endothelial cells and tumor angiogenesis. Cell Death Differ. 2019, 26, 665-679. [CrossRef] [PubMed]

47. Münz, C. Autophagy Beyond Intracellular MHC Class II Antigen Presentation. Trends Immunol. 2016, 37, 755-763. [CrossRef] [PubMed]

48. Fonteneau, J.-F.; Brilot, F.; Münz, C.; Gannagé, M. The Tumor Antigen NY-ESO-1 Mediates Direct Recognition of Melanoma Cells by CD4+ T Cells after Intercellular Antigen Transfer. J. Immunol. 2015, 196, 64-71. [CrossRef]

49. Page, D.B.; Hulett, T.W.; Hilton, T.; Hu, H.-M.; Urba, W.J.; Fox, B.A. Glimpse into the future: Harnessing autophagy to promote anti-tumor immunity with the DRibbles vaccine. J. Immunother. Cancer 2016, 4, 25. [CrossRef]

50. Patterson, N.L.; Mintern, J.D. Intersection of autophagy with pathways of antigen presentation. Protein Cell 2012, 3, 911-920. [CrossRef]

51. Folkerts, H.; Hilgendorf, S.; Vellenga, E.; Bremer, E.; Wiersma, V.R. The multifaceted role of autophagy in cancer and the microenvironment. Med. Res. Rev. 2018, 39, 517-560. [CrossRef] [PubMed]

52. Puleston, D.J.; Zhang, H.; Powell, T.J.; Lipina, E.; Sims, S.; Panse, I.; Watson, A.S.; Cerundolo, V.; Townsend, A.R.M.; Klenerman, P.; et al. Autophagy is a critical regulator of memory CD8+ T cell formation. eLife 2014, 3, e03706. [CrossRef] [PubMed] 
53. Zhou, M.; Wen, Z.; Cheng, F.; Ma, J.; Li, W.; Ren, H.; Sheng, Y.; Dong, H.; Lu, L.; Hu, H.-M.; et al. Tumor-released autophagosomes induce IL-10-producing B cells with suppressive activity on T lymphocytes via TLR2-MyD88-NF-кB signal pathway. OncoImmunology 2016, 5, e1180485. [CrossRef] [PubMed]

54. Koustas, E.; Papavassiliou, A.G.; Karamouzis, M.V. The role of autophagy in the treatment of BRAF mutant colorectal carcinomas differs based on microsatellite instability status. PLoS ONE 2018, 13, e0207227. [CrossRef]

55. Valečka, J.; Almeida, C.R.; Su, B.; Pierre, P.; Gatti, E. Autophagy and MHC-restricted antigen presentation. Mol. Immunol. 2018, 99, 163-170. [CrossRef]

56. Crotzer, V.L.; Blum, J.S. Autophagy and its role in MHC-mediated antigen presentation. J. Immunol. 2009, 182, 3335-3341. [CrossRef]

57. Parekh, V.V.; Wu, L.; Boyd, K.L.; Williams, J.A.; Gaddy, J.A.; Olivares-Villagómez, D.; Cover, T.L.; Zong, W.-X.; Zhang, J.; Van Kaer, L. Impaired autophagy, defective T cell homeostasis, and a wasting syndrome in mice with a T cell-specific deletion of Vps34. J. Immunol. 2013, 190, 5086-5101. [CrossRef]

58. Mintern, J.D.; Macri, C.; Chin, W.J.; Panozza, S.E.; Segura, E.; Patterson, N.L.; Zeller, P.; Bourges, R.; Bedoui, S.; McMillan, P.; et al. Differential use of autophagy by primary dendritic cells specialized in cross-presentation. Autophagy 2015, 11, 906-917. [CrossRef]

59. Ghislat, G.; Lawrence, T. Autophagy in dendritic cells. Cell. Mol. Immunol. 2018, 15, 944-952. [CrossRef]

60. Thiele, F.; Tao, S.; Zhang, Y.; Muschaweckh, A.; Zollmann, T.; Protzer, U.; Abele, R.; Drexler, I. Modified Vaccinia Virus Ankara-Infected Dendritic Cells Present CD4+ T-Cell Epitopes by Endogenous Major Histocompatibility Complex Class II Presentation Pathways. J. Virol. 2014, 89, 2698-2709. [CrossRef]

61. Bronietzki, A.W.; Schuster, M.; Schmitz, I. Autophagy in T-cell development, activation and differentiation. Immunol. Cell Boil. 2014, 93, 25-34. [CrossRef] [PubMed]

62. Durães, F.V.; Niven, J.; Dubrot, J.; Hugues, S.; Gannagé, M. Macroautophagy in Endogenous Processing of Self- and Pathogen-Derived Antigens for MHC Class II Presentation. Front. Immunol. 2015, 6, 79. [CrossRef] [PubMed]

63. You, L.; Mao, L.; Wei, J.; Jin, S.; Yang, C.; Liu, H.; Zhu, L.; Qian, W. The crosstalk between autophagic and endo-/exosomal pathways in antigen processing for MHC presentation in anticancer T cell immune responses. J. Hematol. Oncol. 2017, 10, 165. [CrossRef] [PubMed]

64. Mazzone, R.; Zwergel, C.; Mai, A.; Valente, S. Epi-drugs in combination with immunotherapy: A new avenue to improve anticancer efficacy. Clin. Epigenet. 2017, 9, 59. [CrossRef]

65. Peng, D.; Kryczek, I.; Nagarsheth, N.; Zhao, L.; Wei, S.; Wang, W.; Sun, Y.; Zhao, E.; Vatan, L.; Szeliga, W.; et al. Epigenetic silencing of TH1-type chemokines shapes tumour immunity and immunotherapy. Nature 2015, 527, 249-253. [CrossRef]

66. Kim, K.; Skora, A.D.; Li, Z.; Liu, Q.; Tam, A.J.; Blosser, R.L.; Diaz, L.A.; Papadopoulos, N.; Kinzler, K.W.; Vogelstein, B.; et al. Eradication of metastatic mouse cancers resistant to immune checkpoint blockade by suppression of myeloid-derived cells. Proc. Natl. Acad. Sci. USA 2014, 111, 11774-11779. [CrossRef]

67. Héninger, E.; Krueger, T.E.; Lang, J.M. Augmenting antitumor immune responses with epigenetic modifying agents. Front Immunol. 2015, 6, 29. [CrossRef]

68. Shalabi, H.; Kraft, I.L.; Wang, H.-W.; Yuan, C.M.; Yates, B.; Delbrook, C.; Zimbelman, J.D.; Giller, R.; Stetler-Stevenson, M.; Jaffe, E.S.; et al. Sequential loss of tumor surface antigens following chimeric antigen receptor T-cell therapies in diffuse large B-cell lymphoma. Haematology 2018, 103, e215-e218. [CrossRef]

69. Ready, N.E.; Farago, A.F.; De Braud, F.; Atmaca, A.; Hellmann, M.D.; Schneider, J.G.; Spigel, D.R.; Moreno, V.; Chau, I.; Hann, C.L.; et al. Third-Line Nivolumab Monotherapy in Recurrent SCLC: CheckMate 032. J. Thorac. Oncol. 2019, 14, 237-244. [CrossRef]

70. Restifo, N.P.; Smyth, M.J.; Snyder, A.; Snyder, A. Acquired resistance to immunotherapy and future challenges. Nat. Rev. Cancer 2016, 16, 121-126. [CrossRef]

71. Leclerc, M.; Mezquita, L.; De Nerville, G.G.; Tihy, I.; Malenica, I.; Chouaib, S.; Mami-Chouaib, F. Recent Advances in Lung Cancer Immunotherapy: Input of T-Cell Epitopes Associated With Impaired Peptide Processing. Front. Immunol. 2019, 10, 1505. [CrossRef] [PubMed]

72. Lawrence, M.S.; Stojanov, P.; Polak, P.; Kryukov, G.V.; Cibulskis, K.; Sivachenko, A.; Carter, S.L.; Stewart, C.; Mermel, C.; Roberts, S.A.; et al. Mutational heterogeneity in cancer and the search for new cancer-associated genes. Nature 2013, 499, 214-218. [CrossRef] [PubMed] 
73. Castle, J.C.; Uduman, M.; Pabla, S.; Stein, R.B.; Buell, J.S. Mutation-Derived Neoantigens for Cancer Immunotherapy. Front. Immunol. 2019, 10, 1856. [CrossRef] [PubMed]

74. Van Allen, E.M.; Miao, D.; Schilling, B.; Shukla, S.A.; Blank, C.; Zimmer, L.; Sucker, A.; Hillen, U.; Foppen, M.H.G.; Goldinger, S.M.; et al. Genomic correlates of response to CTLA-4 blockade in metastatic melanoma. Science 2015, 350, 207-211. [CrossRef]

75. Fang, M.J.; Yan, K.; Guo, J. Biological and clinical research progress of MITF in melanoma. Tumors 2013, 33, 1130-1134.

76. Falletta, P.; Del Campo, L.S.; Chauhan, J.; Effern, M.; Kenyon, A.; Kershaw, C.J.; Siddaway, R.; Lisle, R.; Freter, R.; Daniels, M.; et al. Translation reprogramming is an evolutionarily conserved driver of phenotypic plasticity and therapeutic resistance in melanoma. Genes Dev. 2017, 31, 18-33. [CrossRef] [PubMed]

77. Al Emran, A.; Chatterjee, A.; Rodger, E.J.; Tiffen, J.C.; Gallagher, S.; Eccles, M.R.; Hersey, P. Targeting DNA Methylation and EZH2 Activity to Overcome Melanoma Resistance to Immunotherapy. Trends Immunol. 2019, 40, 328-344. [CrossRef] [PubMed]

78. Jiang, X.; Li, L.; Li, Y.; Li, Q. Molecular Mechanisms and Countermeasures of Immunotherapy Resistance in Malignant Tumor. J. Cancer 2019, 10, 1764-1771. [CrossRef] [PubMed]

79. Cortez, M.A.; Anfossi, S.; Ramapriyan, R.; Menon, H.; Atalar, S.C.; Aliru, M.; Welsh, J.; Calin, G.A. Role of miRNAs in immune responses and immunotherapy in cancer. Genes Chromosom. Cancer 2019, 58, $244-253$. [CrossRef]

80. Giri, B.R.; Cheng, G. MicroRNAs, T-cell immunity and immunotherapy. Future Med. Chem. 2019, 11, 2043-2045. [CrossRef]

81. Khan, K.A.; Kerbel, R.S. Improving immunotherapy outcomes with anti-angiogenic treatments and vice versa. Nat. Rev. Clin. Oncol. 2018, 15, 310-324. [CrossRef] [PubMed]

82. Li, Y.-L.; Zhao, H.; Ren, X.-B. Relationship of VEGF/VEGFR with immune and cancer cells: Staggering or forward? Cancer Boil. Med. 2016, 13, 206-214. [CrossRef] [PubMed]

83. Koustas, E.; Sarantis, P.; Theoharis, S.; Saetta, A.A.; Chatziandreou, I.; Kyriakopoulou, G.; Giannopoulou, I.; Michelli, M.; Schizas, D.; Papavassiliou, A.G.; et al. Autophagy-related Proteins as a Prognostic Factor of Patients With Colorectal Cancer. Am. J. Clin. Oncol. 2019, 42, 767-776. [CrossRef] [PubMed]

84. Newton, R.H.; Turka, L.A. Regulation of T Cell Homeostasis and Responses by Pten. Front. Immunol. 2012, 3, 151. [CrossRef]

85. George, S.; Miao, D.; Demetri, G.D.; Adeegbe, D.; Rodig, S.J.; Shukla, S.; Lipschitz, M.; Amin-Mansour, A.; Raut, C.P.; Carter, S.L.; et al. Loss of PTEN Is Associated with Resistance to Anti-PD-1 Checkpoint Blockade Therapy in Metastatic Uterine Leiomyosarcoma. Immunity 2017, 46, 197-204. [CrossRef]

86. Rizvi, N.A.; Chan, T.A. Immunotherapy and Oncogenic Pathways: The PTEN Connection. Cancer Discov. 2016, 6, 128-129. [CrossRef]

87. Shi, D.S.; Zaretsky, J.M.; Escuin-Ordinas, H.; Garcia-Diaz, A.; Hu-Lieskovan, S.; Kalbasi, A.; Grasso, C.S.; Hugo, W.; Sandoval, S.; Torrejon, D.Y.; et al. Primary resistance to PD-1 blockade mediated by JAK1/2 mutations. Cancer Discov. 2017, 7, 188.

88. Luo, N.; Formisano, L.; Ericsson, P.G.; Sánchez, V.; Dean, P.T.; Opalenik, S.R.; Sanders, M.E.; Cook, R.S.; Arteaga, C.L.; Johnson, D.B.; et al. Melanoma response to anti-PD-L1 immunotherapy requires JAK1 signaling, but not JAK2. OncoImmunology 2018, 7, e1438106. [CrossRef]

89. Zaretsky, J.M.; Garcia-Diaz, A.; Shin, D.; Escuin-Ordinas, H.; Hugo, W.; Hu-Lieskovan, S.; Torrejon, D.Y.; Abril-Rodriguez, G.; Sandoval, S.; Barthly, L.; et al. Mutations Associated with Acquired Resistance to PD-1 Blockade in Melanoma. N. Engl. J. Med. 2016, 375, 819-829. [CrossRef]

90. El-Sahli, S.; Xie, Y.; Wang, L.; Liu, S. Wnt Signaling in Cancer Metabolism and Immunity. Cancers 2019, 11, 904. [CrossRef]

91. Spranger, S.; Bao, R.; Gajewski, T.F. Melanoma-intrinsic $\beta$-catenin signalling prevents anti-tumour immunity. Nature 2015, 523, 231-235. [CrossRef] [PubMed]

92. Goldsberry, W.; Londoño, A.; Randall, T.; Norian, L.; Arend, R. A Review of the Role of Wnt in Cancer Immunomodulation. Cancers 2019, 11, 771. [CrossRef] [PubMed]

93. Seliger, B. Different regulation of MHC Class I antigen processing components in human tumors. J. Immunotoxicol. 2008, 5, 361-367. [CrossRef] [PubMed] 
94. Sade-Feldman, M.; Jiao, Y.J.; Chen, J.H.; Rooney, M.S.; Barzily-Rokni, M.; Eliane, J.-P.; Bjorgaard, S.L.; Hammond, M.R.; Vitzthum, H.; Blackmon, S.M.; et al. Resistance to checkpoint blockade therapy through inactivation of antigen presentation. Nat. Commun. 2017, 8, 1136. [CrossRef]

95. Benus, R.F.J.; Van Der Werf, T.S.; Welling, G.W.; Judd, P.A.; Taylor, M.A.; Harmsen, H.J.M.; Whelan, K. Association between Faecalibacterium prausnitzii and dietary fibre in colonic fermentation in healthy human subjects. Br. J. Nutr. 2010, 104, 693-700. [CrossRef]

96. Sivan, A.; Corrales, L.; Hubert, N.; Williams, J.B.; Aquino-Michaels, K.; Earley, Z.M.; Benyamin, F.W.; Lei, Y.M.; Jabri, B.; Alegre, M.-L.; et al. Commensal Bifidobacterium promotes antitumor immunity and facilitates anti-PD-L1 efficacy. Science 2015, 350, 1084-1089. [CrossRef]

97. Chaput, N.; Lepage, P.; Coutzac, C.; Soularue, E.; Le Roux, K.; Monot, C.; Boselli, L.; Routier, E.; Cassard, L.; Collins, M.; et al. Baseline gut microbiota predicts clinical response and colitis in metastatic melanoma patients treated with ipilimumab. Ann. Oncol. 2017, 28, 1368-1379. [CrossRef]

98. Gopalakrishnan, V.; Spencer, C.N.; Nezi, L.; Reuben, A.; Andrews, M.C.; Karpinets, T.V.; Prieto, P.A.; Vicente, D.; Hoffman, K.; Wei, S.C.; et al. Gut microbiome modulates response to anti-PD-1 immunotherapy in melanoma patients. Science 2017, 359, 97-103. [CrossRef]

99. Matson, V.; Fessler, J.; Bao, R.; Chongsuwat, T.; Zha, Y.; Alegre, M.-L.; Luke, J.J.; Gajewski, T.F. The commensal microbiome is associated with anti-PD-1 efficacy in metastatic melanoma patients. Science 2018, 359, 104-108. [CrossRef]

100. Ueda, K.; Yonekura, S.; Ogasawara, N.; Matsunaga, Y.; Hoshino, R.; Kurose, H.; Chikui, K.; Uemura, K.; Nakiri, M.; Nishihara, K.; et al. Impact of antibiotics on outcome in patients with metastatic renal cell carcinoma treated with immune checkpoint inhibitors. J. Clin. Oncol. 2017, 35, 462.

101. Humphries, A.; Daud, A. The gut microbiota and immune checkpoint inhibitors. Hum. Vaccines Immunother. 2018, 14, 2178-2182. [CrossRef] [PubMed]

102. Chilakapati, S.R.; Ricciuti, J.; Zsiros, E. Microbiome and cancer immunotherapy. Curr. Opin. Biotechnol. 2020, 65, 114-117. [CrossRef] [PubMed]

103. Pitt, J.M.; Vétizou, M.; Daillère, R.; Roberti, M.P.; Yamazaki, T.; Routy, B.; Lepage, P.; Boneca, I.G.; Chamaillard, M.; Kroemer, G.; et al. Resistance Mechanisms to Immune-Checkpoint Blockade in Cancer: Tumor-Intrinsic and -Extrinsic Factors. Immunity 2016, 44, 1255-1269. [CrossRef] [PubMed]

104. Frankel, A.E.; Deshmukh, S.; Reddy, A.; Lightcap, J.; Hayes, M.; McClellan, S.; Singh, S.; Rabideau, B.D.; Glover, T.G.; Roberts, B.; et al. Cancer Immune Checkpoint Inhibitor Therapy and the Gut Microbiota. Integr. Cancer Ther. 2019, 18, 1534735419846379. [CrossRef]

105. Gopalakrishnan, V.; Helmink, B.A.; Spencer, C.N.; Reuben, A.; Wargo, J. The Influence of the Gut Microbiome on Cancer, Immunity, and Cancer Immunotherapy. Cancer Cell 2018, 33, 570-580. [CrossRef]

106. Reck, M.; Rodríguez-Abreu, D.; Robinson, A.G.; Hui, R.; Csőszi, T.; Fülöp, A.; Gottfried, M.; Peled, N.; Tafreshi, A.; Cuffe, S.; et al. Pembrolizumab versus Chemotherapy for PD-L1-Positive Non-Small-Cell Lung Cancer. N. Engl. J. Med. 2016, 375, 1823-1833. [CrossRef]

107. Herbst, R.S.; Baas, P.; Kim, D.W.; Felip, E.; Pérez-Gracia, J.L.; Han, J.Y.; Molina, J.; Kim, J.H.; Arvis, C.D.; Ahn, M.J.; et al. Pembrolizumab versus docetaxel for previously treated, PD-L1-positive, advanced nonsmall-cell lung cancer (KEYNOTE-010): A randomised controlled trial. Lancet 2016, 387, 1540-1550. [CrossRef]

108. Signorelli, D.; Giannatempo, P.; Grazia, G.; Aiello, M.M.; Bertolini, F.; Mirabile, A.; Buti, S.; Vasile, E.; Scotti, V.; Pisapia, P.; et al. Patients Selection for Immunotherapy in Solid Tumors: Overcome the Naïve Vision of a Single Biomarker. BioMed Res. Int. 2019, 2019, 9056417. [CrossRef]

109. Yu, H.; Boyle, T.A.; Zhou, C.; Rimm, D.L.; Hirsch, F.R. PD-L1 Expression in Lung Cancer. J. Thorac. Oncol. 2016, 11, 964-975. [CrossRef]

110. Da Silva, C.; Camps, M.G.; Li, T.M.; Zerrillo, L.; Löwik, C.W.; Ossendorp, F.; Cruz, L.J. Effective chemoimmunotherapy by co-delivery of doxorubicin and immune adjuvants in biodegradable nanoparticles. Theranostics 2019, 9, 6485-6500. [CrossRef]

111. Barrueto, L.; Caminero, F.; Cash, L.; Makris, C.; Lamichhane, P.; Deshmukh, R.R. Resistance to Checkpoint Inhibition in Cancer Immunotherapy. Transl. Oncol. 2020, 13, 100738. [CrossRef] [PubMed]

112. Bokas, A.; Papakotoulas, P.; Sarantis, P.; Papadimitropoulou, A.; Papavassiliou, A.G.; Karamouzis, M.V. Mechanisms of the Antitumor Activity of Low Molecular Weight Heparins in Pancreatic Adenocarcinomas. Cancers 2020, 12, 432. [CrossRef] [PubMed] 
113. Gong, J.; Le, T.Q.; Massarelli, E.; Hendifar, A.E.; Tuli, R. Radiation therapy and PD-1/PD-L1 blockade: The clinical development of an evolving anticancer combination. J. Immunother. Cancer 2018, 6, 46. [CrossRef] [PubMed]

114. Wang, X.; Schoenhals, J.E.; Li, A.; Valdecanas, D.R.; Ye, H.; Zang, F.; Tang, C.; Tang, M.; Liu, C.-G.; Liu, X.; et al. Suppression of Type I IFN Signaling in Tumors Mediates Resistance to Anti-PD-1 Treatment That Can Be Overcome by Radiotherapy. Cancer Res. 2016, 77, 839-850. [CrossRef]

115. Ciciola, P.; Cascetta, P.; Bianco, C.; Formisano, L.; Bianco, R. Combining Immune Checkpoint Inhibitors with Anti-Angiogenic Agents. J. Clin. Med. 2020, 9, 675. [CrossRef]

116. Yaghoubi, N.; Soltani, A.; Ghazvini, K.; Hassanian, S.M.; Hashemy, S.I. PD-1/PD-L1 blockade as a novel treatment for colorectal cancer. Biomed. Pharmacother. 2019, 110, 312-318. [CrossRef]

117. Della Gravara, L.; Battiloro, C.; Cantile, R.; Letizia, A.; Vitiello, F.; Montesarchio, V.; Rocco, D. Chemotherapy and/or immune checkpoint inhibitors in NSCLC first-line setting: What is the best approach? Lung Cancer Manag. 2020, 9, LMT22. [CrossRef]

118. Liang, X.; De Vera, M.E.; Buchser, W.; Chavez, A.R.D.V.; Loughran, P.; Stolz, N.B.; Basse, P.; Wang, T.; Van Houten, B.; Zeh, H.J.; et al. Inhibiting systemic autophagy during interleukin 2 immunotherapy promotes long-term tumor regression. Cancer Res. 2012, 72, 2791-2801. [CrossRef]

119. Lotze, M.T.; Buchser, W.; Liang, X. Blocking the interleukin 2 (IL2)-induced systemic autophagic syndrome promotes profound antitumor effects and limits toxicity. Autophagy 2012, 8, 1264-1266. [CrossRef]

120. Li, J.; Yang, D.; Wang, W.; Piao, S.; Zhou, J.; Saiyin, W.; Zheng, C.; Sun, H.; Li, Y. Inhibition of autophagy by 3-MA enhances IL-24-induced apoptosis in human oral squamous cell carcinoma cells. J. Exp. Clin. Cancer Res. 2015, 34, 97. [CrossRef]

121. Li, W.; Deng, Y.; Chu, Q.; Zhang, P. Gut microbiome and cancer immunotherapy. Cancer Lett. 2019, 447, 41-47. [CrossRef] [PubMed]

(C) 2020 by the authors. Licensee MDPI, Basel, Switzerland. This article is an open access article distributed under the terms and conditions of the Creative Commons Attribution (CC BY) license (http://creativecommons.org/licenses/by/4.0/). 